\title{
ORIGINAL
}

\section{Association of the Common Fat Mass and Obesity Associated (FTO) Gene Polymorphism with Obesity in a Japanese Population}

\author{
SHIGERU KARASAWA ${ }^{1)}$, MAKOTO DAIMON ${ }^{1), 2)}$, SATOSHI SASAKI ${ }^{3)}$, SAYUMI TORIYAMA ${ }^{1), 4)}$, \\ TOSHIHIDE OIZUMI ${ }^{1)}$, SHINJI SUSA ${ }^{1)}$, WATARU KAMEDA ${ }^{1)}$, KIRIKO WADA ${ }^{1)}$, MASAAKI MURAMATSU ${ }^{4), 5)}$ \\ AKIRA FUKAO ${ }^{2)}$, ISAO KUBOTA ${ }^{2)}$, SUMIO KAWATA ${ }^{2)}$, TAKAMASA KAYAMA ${ }^{2)}$ AND TAKEO KATO ${ }^{1), 2)}$ \\ ${ }^{1)}$ Third Department of Internal Medicine, Yamagata University Faculty of Medicine, Yamagata, Japan \\ ${ }^{2)}$ Global Center of Excellence Program Study Group, Yamagata University School of Medicine, Yamagata, Japan \\ ${ }^{3}$ Department of Social and Preventive Epidemiology, School of Public Health, the University of Tokyo, Tokyo, Japan \\ ${ }^{4)}$ HuBit Genomix Research Institute, Tokyo, Japan \\ ${ }^{5)}$ Department of Molecular Epidemiology, Medical Research Institute, Tokyo Medical and Dental University, Tokyo, Japan
}

\begin{abstract}
The association of the FTO gene polymorphism, rs9939609, with obesity was examined using the population of the Takahata study (n (M/F): 2,639 (1,168 / 1,470); age: $63.0 \pm 10.2$ years), a Japanese community-based study. The effects of lifestyle-related factors, including nutritional intake and physical activities, on the association were also examined. Body mass index (BMI) was significantly associated with the FTO gene polymorphism $(p<0.001)$. A case-control association study of the FTO gene polymorphism with obesity using multiple logistic regression analysis showed a significant association of the genotype AA (odds ratio, 1.53 [95\% confidential interval, 1.04-2.24]) after adjustment for age and gender. Analysis to examine the differences in lifestyle-related factors among the genotype groups showed a significant difference in the energy expenditure for moderate to high-intensity physical activity (PA) $(\geq 3.0 \mathrm{METs})(p=0.012)$ with a significant decrease toward the genotype AA $(p=0.027)$. The effect of energy expenditure for moderate to high-intensity PA on the association of the polymorphism with obesity was then examined using study groups stratified based on the energy expenditure for moderate to high-intensity PA (Low-PA and High-PA). The BMI was significantly higher in the genotype AA in the Low-PA group $(p=0.016)$ but not in the High-PA group $(p=0.103)$. Furthermore, the genotype AA was significantly associated with obesity (odds ratio, 2.39 [95\% confidential interval, 1.19-4.80]) in the Low-PA group but not in the HighPA group $(p=0.650)$. The FTO gene, rs9939609, was associated with obesity, and the association was evident in subjects with low-PA, suggesting a PA-dependent association.
\end{abstract}

Key words: FTO gene polymorphism, Gene environmental interaction, Physical activity, Nutritional intake, Populationbased study

OBESITY, which is a risk factor for various disorders including type 2 diabetes, hypertension, cancer, and cardiovascular disease, is one of the most common disorders in clinical practice worldwide and, thus, a global public health problem. It has been reported that the occurrence of obesity is determined by both environmental and genetic factors [1]. Increased energy intake and decreased physical activity are such envi-

Received Oct. 14, 2009; Accepted Dec. 8, 2009 as K09E-305 Released online in J-STAGE as advance publication Jan. 6, 2010

Correspondence to: Makoto DAIMON, M.D., Third Department of Internal Medicine, Yamagata University Faculty of Medicine, 2-2-2 Iida-Nishi, Yamagata 990-9585, Japan.

E-mail: mdaimon@med.id.yamagata-u.ac.jp ronmental factors. Genes related to obesity have been frequently searched. Recently, the fat mass and obesity associated (FTO) gene was identified to be associated with obesity by several genome-wide association studies [2-4]. The FTO gene is highly polymorphic, and several polymorphisms of the gene have been found to be associated with obesity or obesity phenotypes, such as high BMI, by case-control studies as well [5-18]. Among such polymorphisms, the polymorphism rs9939609 has been the most studied and wellannotated polymorphism with the allele A to be associated with obesity phenotype [9-18]. Although the association of the FTO gene with obesity is observed across many different ethnic populations [5-18], there 
are several controversies, even among studies with the same ethnic population [19-22]. Among studies with Japanese populations, some showed an association of the FTO gene with obesity $[17,18]$, and some failed to replicate the result [21]. The reason for this discrepancy is not clear. Low frequencies of the at-risk allele and/or low frequencies of obese subjects in the Japanese population may decrease the statistical power of the studies. Lack of adjustment for confounding factors, especially, lifestyle-related factors, may also be the reason, since such environmental factors seem to be important to modulate the gene susceptibility for lifestyle-related disorders such as obesity.

We examined here the association of the FTO gene with obesity in a relatively large population-based Japanese sample with regard to lifestyle-related factors, including nutritional intake and physical activities, since obesity is primarily a consequence of increased nutritional intake and/or decreased energy expenditure.

\section{Materials and Methods}

\section{Subjects}

The Takahata study is a population-based crosssectional study of Japanese people over 35 years old performed to clarify risk factors for certain lifestylerelated conditions, such as diabetes and obesity [23]. Takahata is an agricultural and suburban area about $300 \mathrm{~km}$ north of Tokyo. The population over 35 years of age was 15,819 in Takahata in 2005. From 2004 to $2005,3,165$ residents participated in the Takahata study. Of them, 2,639 subjects (mean age: $63.0 \pm 10.2$ years; sex ratio (men /women): 1,168/1,471) were enrolled in this study.

This study was approved by the Ethics Committee of the Yamagata University School of Medicine, and written informed consent was obtained from all of the participants. Along with the genetic analysis, the following traits were analyzed: height, body weight (BW), fasting plasma glucose (FPG), fasting serum insulin (FI), HbA1c, body mass index (BMI), systolic blood pressure, diastolic blood pressure, total serum cholesterol, serum triglyceride, serum HDL cholesterol, and insulin resistance indexes assessed by homeostasis model assessment using FPG and FI levels (HOMA-R). To precisely evaluate HOMA-R, subjects with FPG levels $\geq 140 \mathrm{mg} / \mathrm{dL}$ were excluded from the analysis $(n=36)$. The clinical characteristics of the study population are shown in Table 1. Individuals who had a BMI of more than $25 \mathrm{~kg} / \mathrm{m}^{2}$ were considered obese $(n=794)$. Diabetes was defined based on the 1998 WHO criteria (FPG levels $\geq 126 \mathrm{mg} / \mathrm{dL}$ ) [24]. In subjects whose FPG levels were not measured, diabetes was defined as postprandial glucose levels $\geq 200$ $\mathrm{mg} / \mathrm{dL}$. Subjects with HbA1c levels $\geq 6.5 \%$ were also defined as diabetic. Those on medication for diabetes were defined as diabetic. Subjects known to have type 1 diabetes were excluded. The number of subjects with diabetes was 215 . In some subjects $(n=1,475)$, the status of daily nutritional intake was estimated using the brief self-administered diet history questionnaire (BDHQ), which requires the recall of dietary habits over a 1-month period $[25,26]$, and the status of current physical activity was assessed using the Japan Arteriosclerosis Longitudinal Study (JALS) Physical Activity Questionnaire (PAQ), which allows total energy and activity-specific energy to be quantified in terms of metabolic equivalent-hour/day (METs-h/day) $[27,28]$. The subjects were stratified into two separate halves based on energy expenditure for moderate to high-intensity physical activity (PA) defined as $\geq 3.0$ METs $(<4.3$ (Low-PA; $n=720)$ and $\geq 4.3$ METs-h/day (High-PA; 715)). Examples of 3.0 METs PA were walking, fishing, and housecleaning. Hypertension was defined as blood pressure $\geq 140 / 90 \mathrm{mmHg}$ or as being on treatment for hypertension. Hyperlipidemia was defined as total cholesterol $\geq 240 \mathrm{mg} / \mathrm{dL}, \mathrm{TG} \geq 150$ $\mathrm{mg} / \mathrm{dL}$ or as being on treatment for hyperlipidemia.

\section{Genotyping}

Genomic DNA was extracted from peripheral blood leukocytes. The genotype of the polymorphism of the FTO gene (db SNP ID: rs9939609) was analyzed with fluorogenic polymerase chain reaction, as previously described [29]. The study population was divided into three groups according to the genotypes: TT $(n=1,680)$, AT $(n=837)$ and AA $(n=122)$. The mean age $( \pm$ SD $)$ and the sex ratio (male/female) of the groups (TT, AT and AA) were $63.0 \pm 10.2$ and 746/934, $63.1 \pm 10.2$ and $366 / 471$, and $63.0 \pm 9.8$ and 56/66, respectively (Table 1). No statistical differences in age or sex ratios were observed among the groups.

\section{Statistical analysis}

Data are given as the means $\pm \mathrm{SD}$. A quantitative association between the genotypes and the trait values (parametric) and a case-control association be- 
Table 1. FTO genotype (rs9939609) differences in clinical characteristics

\begin{tabular}{|c|c|c|c|c|c|c|}
\hline \multirow{2}{*}{ Traits } & & \multicolumn{3}{|c|}{ Genotypes } & \multicolumn{2}{|c|}{$P$} \\
\hline & & TT & AT & AA & & trend \\
\hline Number (Gender: M/F) & $2639(1168 / 1471)$ & $1680(746 / 934)$ & $837(366 / 471)$ & $122(56 / 66)$ & 0.893 & - \\
\hline Age (yr) & $63.0 \pm 10.2$ & $63.0 \pm 10.2$ & $63.1 \pm 10.2$ & $63.0 \pm 9.8$ & 0.985 & - \\
\hline Height $(\mathrm{cm})$ & $156.5 \pm 9.0$ & $156.4 \pm 9.0$ & $156.7 \pm 8.9$ & $156.9 \pm 8.2$ & 0.724 & - \\
\hline Body weight (kg) & $57.7 \pm 10.2$ & $57.2 \pm 10.1$ & $58.2 \pm 10.5$ & $60.1 \pm 9.8$ & $0.002 *$ & $0.003^{*}$ \\
\hline Body mass index $\left(\mathrm{kg} / \mathrm{m}^{2}\right)$ & $23.5 \pm 3.2$ & $23.3 \pm 3.2$ & $23.7 \pm 3.3$ & $24.4 \pm 3.3$ & $0.0004 *$ & $0.0004 *$ \\
\hline Fasting plasma glucose $(\mathrm{mg} / \mathrm{dL})^{\#}$ & $94.1 \pm 16.0$ & $93.8 \pm 15.3$ & $94.8 \pm 17.4$ & $94.0 \pm 15.3$ & 0.296 & - \\
\hline HbAlc $(\%)$ & $5.24 \pm 0.64$ & $5.23 \pm 0.63$ & $5.24 \pm 0.66$ & $5.28 \pm 0.68$ & 0.746 & - \\
\hline Fasting serum insulin $(\mathrm{mU} / \mathrm{mL}){ }^{\#}$ & $5.8 \pm 4.3$ & $5.7 \pm 4.1$ & $6.0 \pm 4.3$ & $6.6 \pm 6.4$ & $0.026^{*}$ & $0.028 *$ \\
\hline HOMA-R ${ }^{\#}$ & $1.35 \pm 1.06$ & $1.31 \pm 0.95$ & $1.41 \pm 1.12$ & $1.56 \pm 1.85$ & $0.011^{*}$ & $0.017 *$ \\
\hline Systolic blood pressure $(\mathrm{mmHg})$ & $134.0 \pm 15.8$ & $133.6 \pm 16.0$ & $134.3 \pm 15.4$ & $137.3 \pm 15.6$ & $0.033 *$ & $0.012 *$ \\
\hline Diastolic blood pressure (mmHg) & $79.3 \pm 10.1$ & $79.0 \pm 10.2$ & $79.4 \pm 9.8$ & $82.0 \pm 9.9$ & $0.007 *$ & $0.002 *$ \\
\hline Total cholesterol (mg/dL) & $200.8 \pm 31.7$ & $200.2 \pm 31.5$ & $202.2 \pm 32.3$ & $198.6 \pm 31.2$ & 0.257 & - \\
\hline Triglyceride (mg/dL) & $105.9 \pm 63.1$ & $106.2 \pm 62.8$ & $104.1 \pm 61.5$ & $112.5 \pm 75.9$ & 0.357 & - \\
\hline HDL cholesterol (mg/dL) & $59.2 \pm 14.6$ & $59.3 \pm 14.8$ & $59.3 \pm 14.5$ & $58.5 \pm 13.4$ & 0.844 & - \\
\hline LDL cholesterol (mg/dL) & $124.1 \pm 29.5$ & $123.2 \pm 30.1$ & $126.4 \pm 28.6$ & $121.6 \pm 27.1$ & $0.023 *$ & 0.58 \\
\hline Adiponectin (mg/dL) & $10.2 \pm 5.6$ & $10.2 \pm 5.6$ & $10.1 \pm 5.6$ & $10.6 \pm 6.6$ & 0.692 & - \\
\hline Obesity: n (\%) & $794(30.1)$ & $477(28.4)$ & $271(32.4)$ & $46(37.7)$ & $0.021 *$ & $0.006^{*}$ \\
\hline Hypertension: n (\%) & $1462(55.4)$ & $915(54.5)$ & $468(55.9)$ & $79(64.8)$ & 0.083 & - \\
\hline Hyperlipidemia: n (\%) & $852(32.3)$ & $544(32.4)$ & $266(31.8)$ & $42(34.4)$ & 0.835 & - \\
\hline Diabetes: n (\%) & $215(8.1)$ & $133(7.9)$ & $71(8.5)$ & $11(9.0)$ & 0.783 & - \\
\hline Diabetes/IFG: n ( \%) & $215(8.1) / 82(3.1)$ & $133(7.9) / 48(2.9)$ & $71(8.5) / 29(3.5)$ & $11(9.0) / 5(4.1)$ & 0.802 & - \\
\hline Stroke: :n (\%) & $62(2.3)$ & $40(2.4)$ & $16(2.3)$ & $6(4.9)$ & 0.122 & - \\
\hline Heart disease: $\mathrm{n}(\%)$ & $277(10.5)$ & $174(10.4)$ & $90(10.8)$ & $13(10.7)$ & 0.953 & - \\
\hline Arteriosclerosis: n (\%) & $26(1.0)$ & $18(1.1)$ & $7(0.9)$ & $1(0.8)$ & 0.837 & - \\
\hline Drinking alcohol: n( \%) & $1078(40.8)$ & $683(40.7)$ & $347(41.5)$ & $48(39.3)$ & 0.809 & - \\
\hline Smoking (Never/Past/Current) & $1820 / 453 / 366$ & $1168 / 295 / 217$ & $576 / 133 / 128$ & $76 / 25 / 21$ & 0.207 & \\
\hline
\end{tabular}

\#: Data were not obtained from some of the subjects (n(TT/AT/AA):1580/787/114).

\#\#: Subjects whose fasting plasma glucose levels were more than $140 \mathrm{mg} / \mathrm{dL}$ were excluded (n(TT/AT/AA):1554/771/111). Differences in the trait values (parametric) and the frequencies of the conditions (parametric) among the genotype groups were analyzed by the ANOVA and Chi-square tests, respectively. $P<0.05$ is indicated by *.

tween the genotypes and the frequencies of the condition (non-parametric) were analyzed by analysis of variance (ANOVA) and Chi-square tests, respectively. $\mathrm{P}$ values for trends were calculated, when $p$ values for ANOVA were $<0.050$. The independent association of the FTO gene polymorphism from factors such as age and gender was examined by analysis of covariance (ANCOVA) and multiple logistic regression analysis for parametric and non-parametric data, respectively. $P<0.050$ was accepted as significant.

\section{Results} Association of the common FTO gene polymor-
phism, rs9939609, with BMI

As shown in Table 1, BMI, an indicative marker of obesity, was significantly different among the geno- type groups $(p<0.001)$ and significantly increased toward the genotype AA $(p<0.001)$. The association of the polymorphism with BMI was still significant after adjustment for age and gender using ANCOVA $(p<0.001)$. Several obesity-related traits such as FI, HOMA-R, and blood pressure, were also significantly different among the genotype groups, with a significant increase toward the genotype AA. Adjustment for these factors made the association of the polymorphism with BMI insignificant ( $p=0.115$ ). Serum LDL cholesterol levels were significantly different among the genotype groups, but these differences did not have any allele-specific trend and therefore could not be explained as an effect of the polymorphism.

The study subjects included those with medications for diabetes $(n=153)$, hypertension $(n=897)$, and hyperlipidemia $(n=400)$. These conditions could affect 
Table 2. FTO genoytpe (rs9939609) differences in nutritional intake and energy expenditure

\begin{tabular}{|c|c|c|c|c|c|c|}
\hline & \multirow[b]{2}{*}{ total } & \multicolumn{3}{|c|}{ Genotype } & \multicolumn{2}{|l|}{$P$} \\
\hline & & TT & AT & $\mathrm{AA}$ & ANCOVA $^{\#}$ & trend \\
\hline \multicolumn{7}{|l|}{ Nutritional Intake } \\
\hline Number (Gender:M/F) & $1473(633$ / 840) & 950 & 456 & 67 & & \\
\hline Total energy consumption (kcal) & $2241 \pm 681(2425 \pm 729 / 2102 \pm 608)$ & $2236 \pm 696$ & $2270 \pm 665$ & $2109 \pm 564$ & 0.128 & - \\
\hline Total energy consumption/BW (kcal/kg) & $39.7 \pm 13.1(39.2 \pm 12.7 / 40.1 \pm 13.5)$ & $39.9 \pm 13.4$ & $39.8 \pm 12.7$ & $35.7 \pm 11.3$ & $0.043^{*}$ & $0.010^{*}$ \\
\hline Carbohydrate (gr) & $324 \pm 95(347 \pm 105 / 306 \pm 83)$ & $323 \pm 98$ & $326 \pm 90$ & $316 \pm 96$ & 0.589 & - \\
\hline Fat (gr) & $57.7 \pm 23.3(56.5 \pm 23.4 / 58.6 \pm 23.1)$ & $57.5 \pm 23.3$ & $58.7 \pm 23.9$ & $52.9 \pm 17.9$ & 0.163 & - \\
\hline Protein (gr) & $77.3 \pm 31.7(78.4 \pm 32.1 / 76.5 \pm 31.3)$ & $77.0 \pm 31.6$ & $79.2 \pm 33.0$ & $69.1 \pm 21.1$ & $0.048^{*}$ & $0.047^{*}$ \\
\hline \multicolumn{7}{|l|}{ Energy expenditure (METs-h/day) } \\
\hline Number(Gender: $\mathrm{M} / \mathrm{F}$ ) & $1435(619$ / 816) & 917 & 453 & 65 & & \\
\hline Total & $36.04 \pm 5.68(35.74 \pm 5.91 / 36.27 \pm 5.50)$ & $36.2 \pm 5.9$ & $35.8 \pm 5.3$ & $35.0 \pm 4.4$ & 0.13 & 0.118 \\
\hline Low -intensity PA (<3METs) & $28.70 \pm 5.41(27.33 \pm 6.02 / 29.73 \pm 4.52)$ & $28.4 \pm 5.4$ & $29.1 \pm 5.2$ & $29.7 \pm 4.5$ & $0.027^{*}$ & 0.074 \\
\hline Moderate to high-intensity PA ( $\geq 3 \mathrm{METs}$ ) & $7.34 \pm 8.43(8.40 \pm 9.70 / 6.54 \pm 7.21)$ & $7.79 \pm 8.9$ & $6.73 \pm 7.8$ & $5.40 \pm 5.5$ & $0.012 *$ & $0.027 *$ \\
\hline
\end{tabular}

\#: Adjusted for age and gender. $P<0.05$ is indicated by *.

the results. Therefore, we examined the differences in clinical characteristics among the genotype groups only with the subjects who did not take such medications. The results were similar to those obtained with all subjects. BMI was significantly different in the analyses with the subjects who were taking medication for diabetes ( $p=0.001)$, hypertension $(p=0.024)$, or hyperlipidemia $(p<0.001)$. The results for other clinical characteristics were also similar to those obtained with all subjects except for those for HOMA-R and FI. The differences in HOMA-R and FI among the genotype groups became insignificant $(p=0.196$ and 0.209 , respectively) when the subjects who were taking medication for diabetes were excluded, although the results maintained a similar tendency to that observed in those with all subjects.

\section{Lifestyle-dependent association of the common FTO gene polymorphism, rs9939609, with obesity}

We also examined the differences in lifestyle-related factors among the genotype groups. As shown in Table 2, although total nutritional intake was not significantly different among the genotype groups, total nutritional intake per $1 \mathrm{~kg}$ of BW (BW-dependent energy consumption) was significantly different among the genotype groups $(p=0.043)$ with the least being the genotype AA. Total energy expenditure was not significantly different among the genotype groups either. However, energy expenditure for moderate to highintensity PA ( $\geq 3.0$ METs) was significantly different among the genotype groups $(p=0.012)$ with a signifi- cant decrease toward the genotype AA ( $p=0.027)$.

The frequencies of obese subjects were significantly different among the genotype groups $(p=0.021)$ (Table 1). Multiple logistic regression analysis showed that the genotypes AA and AT were significantly associated with obesity, with an OR of 1.53 (95\% CI, 1.04-2.24; $p=0.029)$ and 1.21 (95\% CI, 1.01-1.45; $p=0.040)$, respectively, after adjustment for age and gender (Table 3 ). The effects of energy expenditure for moderate to high-intensity PA on the association of the polymorphism with obesity were then examined using study groups stratified based on energy expenditure for moderate to high-intensity PA (Low-PA and High-PA). In the Low-PA group, the BMI was significantly higher in the genotype AA $(p=0.016)$, but in the High-PA group, the BMI was not significantly different among the genotype groups ( $p=0.103)$ (Fig. 1). Furthermore, significant differences in the frequencies of obese subjects among the genotype groups of the polymorphism were observed in the Low-PA group $(p=0.044)$ but not in the High-PA group ( $p=0.478)$ (Table 3$)$. Multiple logistic regression analysis showed that the genotype AA of the FTO gene polymorphism was significantly associated with obesity, with an OR of 2.39 (95\% CI, $1.19-4.80 ; p=0.014)$, independently of age and gender in the Low-PA group but not in the High-PA group $(p=0.650)$ (Table 3$)$.

\section{Discussion}

The association of the FTO gene polymorphism 
Table 3. Association of the FTO polymorphism (rs 9939609) with obesity (or overweight)

\begin{tabular}{|c|c|c|c|c|}
\hline Genotypes & Obese & Non-obese & OR $(95 \% \mathrm{CI})$ & $p$ \\
\hline \multicolumn{5}{|l|}{ All subjects $(n=2.639)$} \\
\hline TT & $477(28.4)$ & $1203(71.6)$ & 1 & Ref \\
\hline TA & $271(32.4)$ & $566(67.6)$ & $1.21(1.01-1.45)$ & $0.040^{*}$ \\
\hline AA & $46(37.7)$ & $76(62.3)$ & $1.53(1.04-2.24)$ & $0.029 *$ \\
\hline \multicolumn{5}{|c|}{ Modarte to high-intensity PA $<4.3$ METs-h/day (Low-PA) $(\mathrm{n}=720)$} \\
\hline TT & $124(28.5)$ & $311(71.5)$ & 1 & Ref \\
\hline TA & $77(30.8)$ & $173(69.2)$ & $1.11(0.79-1.57)$ & 0.535 \\
\hline AA & $17(48.6)$ & $18(51.4)$ & $2.39(1.19-4.80)$ & $0.014 *$ \\
\hline \multicolumn{5}{|c|}{ Modarte to high-intensity PA $\geq 4.3$ METs-h/day (High-PA) $(n=715)$} \\
\hline TT & $128(26.6)$ & $354(73.4)$ & 1 & Ref \\
\hline TA & $63(31.0)$ & $140(69.0)$ & $1.23(0.86-1.77)$ & 0.259 \\
\hline $\mathrm{AA}$ & $9(30.0)$ & $21(70.0)$ & $1.21(0.54-2.71)$ & 0.650 \\
\hline
\end{tabular}

Numbers of obese and non-obese subjects of each genotype are shown as $\mathrm{N}(\%)$.

Multiple logistic regression analysis was applied with adjustment for age and gender. $P<0.05$ is indicated by *.

with obesity was shown by both quantitative (namely, in regard to BMI) and case-control association analyses in a Japanese sample. The polymorphism was also significantly associated with several clinical traits representing insulin resistance such as HOMA-R and blood pressure (Table 1). When these factors (HOMA-R and blood pressure) were included as covariates in the analysis to examine the association with BMI, they remained significant factors, while the polymorphism of the FTO gene became insignificant. These facts indicate that insulin resistance could be the factor mediating between the FTO gene polymorphism and obesity. Whether the increased insulin resistance in the at-risk genotype groups of the polymorphism indicates functional involvement of FTO in the pathophysiology leading to obesity or is just a marker related to obesity cannot be explained in this study and should therefore be clarified in the future.

Although FTO is widely expressed in many tissues, it is highly expressed in the arcuate nucleus of the hypothalamus $[2,30,31]$, and its expression is regulated by fasting and feeding in mice $[31,32]$, indicating a functional involvement of the gene in the central control of energy homeostasis [33]. Recently, several studies showed an association of the FTO gene polymorphisms with increased energy intake [33-36]. However, most of them were studies with children to examine their habitual appetite behavior, and the positive results shown in them were the association of the polymorphisms with limited parameters such as preference for energy-dense foods and reduced satiety-re- sponsiveness scores [33-35]. A study with a relatively small number of subjects showed increased energy intake for the genotypes at risk for obesity, although in the study BMI was not significantly different among the genotypes [36]. Lack of association of the FTO gene polymorphism with energy expenditure was reported in studies with relatively small numbers of sub-

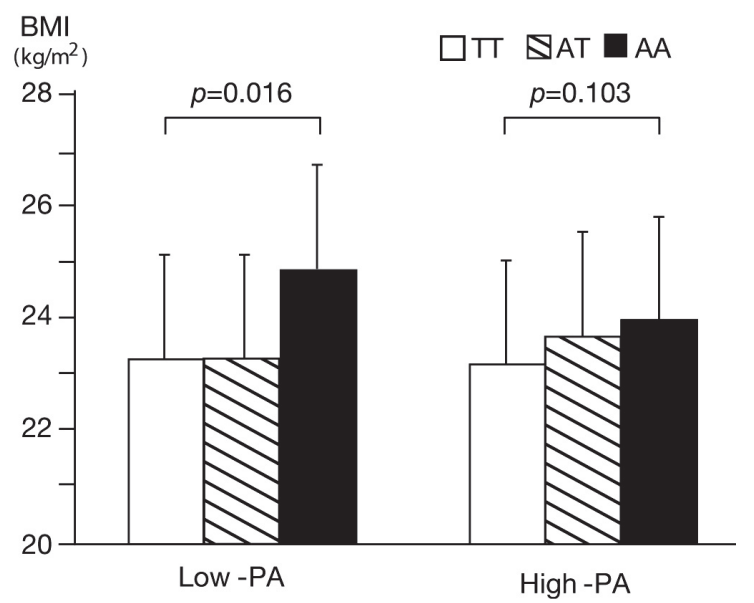

Fig. 1. Moderate to high-intensity physical activity-dependent association of the FTO gene polymorphism, rs9939609, with BMI. The distribution of BMI according to the genotypes of the FTO gene polymorphism is shown. The subjects were stratified into two groups based on energy expenditure for moderate to high-intensity PA (LowPA $(n=720)$ and High-PA $(n=715))$. The bars above the columns represent the standard error (SE). $P$-values were adjusted for age and gender by analysis of covariance (ANCOVA). 
jects [36.37]. Therefore, the association of the FTO gene polymorphism with energy intake and expenditure has not been thoroughly clarified. Very recently, a study with FTO knockout mice showed that the loss of FTO led to a significant reduction in adipose tissue and lean body mass, which was attributed to increased energy expenditure and systemic sympathetic activation [38]. This report indicates that the FTO gene polymorphism primarily acts as the cause of obesity through mechanisms related to a decrease in energy expenditure.

In this study, the subjects with the genotype AA (at risk for obesity) had significantly less nutritional intake than those with the other genotypes and, thus, the decreased nutritional intake cannot account for the obese phenotype of the genotype AA. Therefore, the subjects with the genotype AA may have even decreased energy expenditure enough to overcome the protective effect of the decreased nutritional intake against becoming obesity. However, total energy expenditure was not significantly different among the genotype groups either. Taken together, these facts together may indicate that lifestyle parameters related to energy homeostasis do not have a substantial enough impact on the effect of the FTO gene polymorphism on the development of obesity to be identified in this kind of analysis. In most adult cases of obesity, BW increases gradually to a level of obesity in middle to old ages: In other words, the development of obesity typically takes a long time, and the effect of a gene on differences in parameters related to energy homeostasis is expected to be small or subtle. We, thus, examined in detail the differences in energy expenditure to identify such subtle differences and found that energy expenditure for moderate to high-intensity PA was significantly decreased in the at-risk genotype groups. Therefore, although subjects with the at-risk genotypes may not have decreased total energy expenditure, they may prefer to avoid moderate to high-intensity PA. This preference seems to account for the obese phenotype observed in relation to the FTO gene polymorphism, although the mechanisms that link the FTO gene with such preference should be clarified in the future.

We then examined the association of the polymorphism with obesity using study groups stratified based on energy expenditure for moderate to high-intensity PA (Low-PA and High-PA) and found a significant association of the FTO gene polymorphism only in those with low-PA. A study examining the association of another FTO gene polymorphism, rs1861868, with BMI also showed a significant association only in subjects with low physical activity scores [39]. This polymorphism, however, was reported to be located in a different linkage disequilibrium (LD) block from that is composed of the polymorphism, rs9939609, used in our study [39]. These results together indicate the clinically useful implication that an increase in moderate to high-intensity PA can diminish susceptibility to obesity derived from the at-risk genotypes of the FTO gene polymorphisms.

We reported here that the subjects with the genotype AA had significantly higher frequency of obesity compared to those with the genotype TT in the subjects with low-PA. However, in this analysis, the subjects with the genotype AT did not have significantly higher frequency of obesity compared to those with the genotype TT. This result did not seem to be in concordance with the results that, when all subjects were analyzed, the subjects with both the genotypes AA and AT had significantly higher frequencies of obesity than those with the genotype TT. This fact can be attributed to the low impact of the genotype AT on the association and the limited number of the subjects for the analysis, or the low statistical power of the analysis. The statistical powers estimated using the software Sampsize (http://sampsize.sourceforge.net/iface/ index.html) were about $9 \%$ to detect an OR of 1.10 at a level of significance of 0.05 for the difference in the frequency between the genotypes AT and TT, while it was about $70 \%$ to detect an OR of 2.39 at a level of significance of 0.05 for the difference in the frequency between the genotypes AA and TT. For the analysis of the subjects with high-PA, the statistical powers were also low; about $17 \%$ and $7 \%$ to detect an OR of 1.20 at a level of significance of 0.05 for the difference in the frequency between the genotypes AT and TT, and, AA and TT, respectively. Therefore, because of the low statistical power, the insignificant results observed in the analysis for the subjects with high-PA cannot be emphasized, although it can be said that the FTO gene polymorphism appeared to have, if any, only a weak association with obesity in the subjects with high-PA.

Associations of the FTO gene polymorphism with obesity have been examined in several studies with conflicting results [5-22]. The finding in which the association of the FTO gene polymorphism with obesity seems to depend on moderate to high-intensity PA might explain the inconsistencies in previous studies. 
Namely, studies of subjects with low-PA might have shown a significant association, whereas studies of subjects with high-PA might not. Studies that take PA into account should be carried out across more extensive and diverse populations in the future to confirm the association reported here.

Since obesity is a risk factor for diabetes, the association of the FTO gene polymorphism with diabetes was also evaluated, but no significant association was shown (Table 1).
In conclusion, the FTO gene polymorphism, rs9939609, was found to be associated with obesity. The association was shown to be evident in subjects with low-PA, suggesting a PA-dependent association.

\section{Acknowledgement}

This work was supported in part by the Global Center of Excellence Program (no. F03) founded by the Japan Society for the Promotion of Science, Japan.

\section{References}

1. Blakemore AI, Froguel P (2008) Is obesity our genetic legacy? J Clin Endocrinol Metab 93(Suppl 1): S51-56.

2. Frayling TM, Timpson NJ, Weedon MN, Zeggini E, Freathy RM, Lindgren CM, Perry JR, Elliott KS, Lango H, Rayner NW, Shields B, Harries LW, Barrett JC, Ellard S, Groves CJ, Knight B, Patch AM, Ness AR, Ebrahim S, Lawlor DA, Ring SM, Ben-Shlomo Y, Jarvelin MR, Sovio U, Bennett AJ, Melzer D, Ferrucci L, Loos RJ, Barroso I, Wareham NJ, Karpe F, Owen KR, Cardon LR, Walker M, Hitman GA, Palmer CN, Doney AS, Morris AD, Smith GD, Hattersley AT, McCarthy MI (2007) A common variant in the FTO gene is associated with body mass index and predisposes to childhood and adult obesity. Science 316: 889894.

3. Thorleifsson G, Walters GB, Gudbjartsson DF, Steinthorsdottir V, Sulem P, Helgadottir A, Styrkarsdottir U, Gretarsdottir S, Thorlacius S, Jonsdottir I, Jonsdottir T, Olafsdottir EJ, Olafsdottir GH, Jonsson T, Jonsson F, Borch-Johnsen K, Hansen T, Andersen G, Jorgensen T, Lauritzen T, Aben KK, Verbeek AL, Roeleveld N, Kampman E, Yanek LR, Becker LC, Tryggvadottir L, Rafnar T, Becker DM, Gulcher J, Kiemeney LA, Pedersen O, Kong A, Thorsteinsdottir U, Stefansson K (2009) Genome-wide association yields new sequence variants at seven loci that associate with measures of obesity. Nat Genet 41: 18-24.

4. Meyre D, Delplanque J, Chèvre JC, Lecoeur C, Lobbens S, Gallina S, Durand E, Vatin V, Degraeve F, Proença C, Gaget S, Körner A, Kovacs P, Kiess W, Tichet J, Marre M, Hartikainen AL, Horber F, Potoczna N, Hercberg S, Levy-Marchal C, Pattou F, Heude B, Tauber M, McCarthy MI, Blakemore AI, Montpetit A, Polychronakos C, Weill J, Coin LJ, Asher J, Elliott P, Järvelin MR, Visvikis-Siest S, Balkau B, Sladek R, Balding D, Walley A, Dina C, Froguel P (2009) Genome-wide association study for early-onset and morbid adult obesity identifies three new risk loci in
European populations. Nat Genet 41: 157-159.

5. Cha SW, Choi SM, Kim KS, Park BL, Kim JR, Kim JY, Shin HD (2008) Replication of genetic effects of FTO polymorphisms on BMI in a Korean population. Obesity 16: 2187-2189.

6. Hubacek JA, Bohuslavova R, Kuthanova L, Kubinova R, Peasey A, Pikhart H, Marmot MG, Bobak M (2008) The FTO gene and obesity in a large Eastern European population sample: the HAPIEE study. Obesity 16: 2764-2766.

7. Ng MC, Park KS, Oh B, Tam CH, Cho YM, Shin HD, Lam VK, Ma RC, So WY, Cho YS, Kim HL, Lee HK, Chan JC, Cho NH (2008) Implication of genetic variants near TCF7L2, SLC30A8, HHEX, CDKAL1, CDKN2A/B, IGF2BP2, and FTO in type 2 diabetes and obesity in 6,719 Asians. Diabetes 57: 2226-2233.

8. Rong R, Hanson RL, Ortiz D, Wiedrich C, Kobes S, Knowler WC, Bogardus C, Baier LJ (2009) Association analysis of variation in/near FTO, CDKAL1, SLC30A8, HHEX, EXT2, IGF2BP2, LOC387761, and CDKN2B with type 2 diabetes and related quantitative traits in Pima Indians. Diabetes 58: 478-488.

9. Wing MR, Ziegler J, Langefeld CD, Ng MC, Haffner SM, Norris JM, Goodarzi MO, Bowden DW (2009) Analysis of FTO gene variants with measures of obesity and glucose homeostasis in the IRAS Family Study. Hum Genet 125: 615-626.

10. Villalobos-Comparán M, Teresa Flores-Dorantes M, Teresa Villarreal-Molina M, Rodríguez-Cruz M, García-Ulloa AC, Robles L, Huertas-Vázquez A, Saucedo-Villarreal N, López-Alarcón M, SánchezMuñoz F, Domínguez-López A, Gutiérrez-Aguilar R, Menjivar M, Coral-Vázquez R, Hernández-Stengele G, Vital-Reyes VS, Acuña-Alonzo V, Romero-Hidalgo S, Ruiz-Gómez DG, Riaño-Barros D, Herrera MF, Gómez-Pérez FJ, Froguel P, García-García E, Teresa Tusié-Luna M, Aguilar-Salinas CA, CanizalesQuinteros S (2008) The FTO gene is associated with adulthood obesity in the Mexican population. Obesity 
16: 2296-2301.

11. Tan JT, Dorajoo R, Seielstad M, Sim XL, Ong RT, Chia KS, Wong TY, Saw SM, Chew SK, Aung T, Tai ES (2008) FTO variants are associated with obesity in the Chinese and Malay populations in Singapore. Diabetes 57: 2851-2857.

12. Qi L, Kang K, Zhang C, van Dam RM, Kraft P, Hunter D, Lee CH, Hu FB (2008) Fat mass-and obesity-associated (FTO) gene variant is associated with obesity: longitudinal analyses in two cohort studies and functional test. Diabetes 57: 3145-3151

13. Franks PW, Jablonski KA, Delahanty LM, McAteer JB, Kahn SE, Knowler WC, Florez JC; Diabetes Prevention Program Research Group (2008) Diabetes Prevention Program Research Group. Assessing genetreatment interactions at the FTO and INSIG2 loci on obesity-related traits in the Diabetes Prevention Program. Diabetologia 51: 2214-2223.

14. Sjögren M, Lyssenko V, Jonsson A, Berglund G, Nilsson P, Groop L, Orho-Melander M (2008) The search for putative unifying genetic factors for components of the metabolic syndrome. Diabetologia 51: 2242-2251.

15. Legry V, Cottel D, Ferrières J, Arveiler D, Andrieux N, Bingham A, Wagner A, Ruidavets JB, Ducimetière P, Amouyel P, Meirhaeghe A (2009) Effect of an FTO polymorphism on fat mass, obesity, and type 2 diabetes mellitus in the French MONICA Study. Metabolism 58: 971-975.

16. Yajnik CS, Janipalli CS, Bhaskar S, Kulkarni SR, Freathy RM, Prakash S, Mani KR, Weedon MN, Kale SD, Deshpande J, Krishnaveni GV, Veena SR, Fall CH, McCarthy MI, Frayling TM, Hattersley AT, Chandak GR (2009) FTO gene variants are strongly associated with type 2 diabetes in South Asian Indians. Diabetologia 52: 247-252.

17. Hotta K, Nakata Y, Matsuo T, Kamohara S, Kotani K, Komatsu R, Itoh N, Mineo I, Wada J, Masuzaki H, Yoneda M, Nakajima A, Miyazaki S, Tokunaga K, Kawamoto M, Funahashi T, Hamaguchi K, Yamada K, Hanafusa T, Oikawa S, Yoshimatsu H, Nakao K, Sakata T, Matsuzawa Y, Tanaka K, Kamatani N, Nakamura Y (2008) Variations in the FTO gene are associated with severe obesity in the Japanese. J Hum Genet 53: 546553.

18. Omori S, Tanaka Y, Takahashi A, Hirose H, Kashiwagi A, Kaku K, Kawamori R, Nakamura Y, Maeda S (2008) Association of CDKAL1, IGF2BP2, CDKN2A/B, HHEX, SLC30A8, and KCNJ11 with susceptibility to type 2 diabetes in a Japanese population Diabetes 57: 791-795.

19. Hennig BJ, Fulford AJ, Sirugo G, Rayco-Solon P, Hattersley AT, Frayling TM, Prentice AM (2009) FTO gene variation and measures of body mass in an African population. BMC Med Genet 5: 10:21.
20. Jacobsson JA, Klovins J, Kapa I, Danielsson P, Svensson V, Ridderstråle M, Gyllensten U, Marcus C, Fredriksson R, Schiöth HB (2008) Novel genetic variant in FTO influences insulin levels and insulin resistance in severely obese children and adolescents. Int $J$ Obes 32: 1730-1735.

21. Horikoshi M, Hara K, Ito C, Shojima N, Nagai R, Ueki K, Froguel P, Kadowaki T (2007) Variations in the HHEX gene are associated with increased risk of type 2 diabetes in the Japanese population. Diabetologia 50: 2461-2466.

22. Li H, Wu Y, Loos RJ, Hu FB, Liu Y, Wang J, Yu Z, Lin $\mathrm{X}$ (2008) Variants in the fat mass- and obesity-associated (FTO) gene are not associated with obesity in a Chinese Han population. Diabetes 57: 264-268.

23. Daimon M, Sato H, Sasaki S, Toriyama S, Emi M, Muramatsu M, Hunt SC, Hopkins PN, Karasawa S, Wada K, Jimbu Y, Kameda W, Susa S, Oizumi T, Fukao A, Kubota I, Kawata S, Kato T (2008) Salt consumption-dependent association of the GNB3 gene polymorphism with type 2 DM. Biochem Biophys Res Commun 374: 576-580.

24. Alberti KG, Zimmet PZ (1998) Definition, diagnosis and classification of diabetes mellitus and its complications. Part 1: diagnosis and classification of diabetes mellitus. Provisional report of a WHO Consultation. Diabet Med 15: 539-553.

25. Sasaki S (2004) Development and evaluation of dietary assessment methods using biomarkers and diet history questionnaires for individuals. In: Tanaka $\mathrm{H}$ (ed) Research for evaluation methods of nutrition and dietary lifestyle programs held on Healthy Japan 21. Summary report. Ministry of Health, Welfare, and Labour, Tokyo: 10-44.

26. Sasaki S, Yanagibori R, Amano K (1998) Validity of a self-administered diet history questionnaire for assessment of sodium and potassium - Comparison with single 24-hour urinary excretion. Jpn Cir J 62: 431-435.

27. Harada A, Naito Y, Inoue S, Kitabatake Y, Arao T, Ohashi Y, JALS Group (2003) Validity of a questionnaire for assessment of physical activity in the japan arteiosclerosis longitudinal study. Med Sci Sports Excer 35(supple 1): S340.

28. Miyabara Y, Onoe Y, Harada A, Kuroda T, Sasaki S, Ohta H (2007) Effect of physical activity and nutrition on bone mineral density in young Japanese women. $J$ Bone Miner Metab 25: 414-418.

29. Ranade K, Chang MS, Ting CT, Pei D, Hsiao CF, Olivier M, Pesich R, Hebert J, Chen YD, Dzau VJ, Curb D, Olshen R, Risch N, Cox DR, Botstein D (2001) High-throughput genotyping with single nucleotide polymorphism. Genome Res 11: 1262-1268.

30. Dina C, Meyre D, Gallina S, Durand E, Körner A, Jacobson P, Carlsson LM, Kiess W, Vatin V, Lecoeur C, Delplanque J, Vaillant E, Pattou F, Ruiz J, Weill J, 
Levy-Marchal C, Horber F, Potoczna N, Hercberg S, Le Stunff C, Bougnères P, Kovacs P, Marre M, Balkau $\mathrm{B}$, Cauchi S, Chèvre JC, Froguel P (2007) Variation in FTO contributes to childhood obesity and severe adult obesity. Nat Genet 39: 724-726.

31. Gerken T, Girard CA, Tung YC, Webby CJ, Saudek V, Hewitson KS, Yeo GS, McDonough MA, Cunliffe S, McNeill LA, Galvanovskis J, Rorsman P, Robins P, Prieur X, Coll AP, Ma M, Jovanovic Z, Farooqi IS, Sedgwick B, Barroso I, Lindahl T, Ponting CP, Ashcroft FM, O'Rahilly S, Schofield CJ (2007) The obesity-associated FTO gene encodes a 2-oxoglutaratedependent nucleic acid demethylase. Science 318: 1469-1472.

32. Fredriksson R, Hägglund M, Olszewski PK, Stephansson O, Jacobsson JA, Olszewska AM, Levine AS, Lindblom J, Schiöth HB (2008) The obesity gene, FTO, is of ancient origin, up-regulated during food deprivation and expressed in neurons of feeding-related nuclei of the brain. Endocrinology 149: 2062-2071.

33. Cecil JE, Tavendale R, Watt P, Hetherington MM, Palmer CN (2008) An obesity-associated FTO gene variant and increased energy intake in children. $N$ Engl J Med 359: 2558-2566.

34. Wardle J, Carnell S, Haworth CM, Farooqi IS,
O'Rahilly S, Plomin R (2008) Obesity associated genetic variation in FTO is associated with diminished satiety. J Clin Endocrinol Metab 93: 3640-3643.

35. Timpson NJ, Emmett PM, Frayling TM, Rogers I, Hattersley AT, McCarthy MI, Davey Smith G (2008) The fat mass- and obesity-associated locus and dietary intake in children. Am J Clin Nutr 88: 971-978.

36. Speakman JR, Rance KA, Johnstone AM (2008) Polymorphisms of the FTO gene are associated with variation in energy intake, but not energy expenditure. Obesity 16: 1961-1965.

37. Berentzen T, Kring SI, Holst C, Zimmermann E, Jess T, Hansen T, Pedersen O, Toubro S, Astrup A, Sørensen TI (2008) Lack of association of fatness-related FTO gene variants with energy expenditure or physical activity. J Clin Endocrinol Metab 93: 2904-2908.

38. Fischer J, Koch L, Emmerling C, Vierkotten J, Peters T, Brüning JC, Rüther U (2009) Inactivation of the Fto gene protects from obesity. Nature 458: 894-898.

39. Rampersaud E, Mitchell BD, Pollin TI, Fu M, Shen H, O’Connell JR, Ducharme JL, Hines S, Sack P, Naglieri R, Shuldiner AR, Snitker S (2008) Physical activity and the association of common FTO gene variants with body mass index and obesity. Arch Intern Med 168: 1791-1797. 